\title{
EFEKTIVITAS PELATIHAN KOPING RELIGIUS UNTUK MENINGKATKAN RESILIENSI PADA PEREMPUAN PENYINTAS ERUPSI MERAPI
}

\section{THE EFFECTIVENESS OF THE RELIGIOUS COPING TRAINING TO ENHANCE THE RESILIENCE LEVEL OF WOMEN SURVIVOR MERAPI ERUPTION}

\author{
Mita Octarina \\ Fakultas Psikologi dan IImu Sosial Budaya Universitas Islam Indonesia Yogyakarta \\ E-mail: mita_oct@yahoo.com \\ Tina Afiatin \\ Fakultas Psikologi Universitas Gadjah Mada Yogyakarta
}

\begin{abstract}
This research examined the effectiveness of the religious coping training to enhance the resilience level of women survivor Merapi eruption. Religious coping training was applying Pargament at al theory (2011), according to which, religious coping was grouped into positive and negative pattern. The positive pattern applied in the research reflects secure relationship with god, beliving that there is a greater meaning to be found in life. In this pattern, god is considered as the greatest, the merciful.This research was nonrandomized pretest-posttest control group design. The research involved several women who survived Merapi eruption. The measurement instruments of the research were resilience scale, observation and interview. Resilience scale employed in this research was a modification from Yu and Zhang resilience scale. The research used mann-whitnney analysis with gained score. The result of mann-whitnney analysis presented a significant difference of resilience score in posttest measurement between experiment group and control group, indicated by $F=-3,210, P=0,001(P<0,01)$. The result concluded that religious coping training was effective for enhancing the resilience level of the women.
\end{abstract}

Key words: religious coping, resilience

\begin{abstract}
ABSTRAK
Penelitian ini bertujuan untuk menguji efektivitas pelatihan koping religius dalam meningkatkan resiliensi pada perempuan penyintas erupsi Merapi. Pelatihan koping religius dalam penelitian ini berdasarkan pada teori Pargament dkk (2011). Menurut Pargament, koping religius dibagi menjadi dua, yaitu koping religius positif dan negatif. Penelitian ini menggunakan koping religius positif, yang merefleksikan hubungan yang aman dengan Tuhan, dan yakin bahwa terdapat makna besar dalam menjalani kehidupan. Tuhan dianggap sebagai murah hati, dan pemaaf dan penuh kasih sayang. Penelitian ini menggunakan non random pretest-posttest control group design. Subjek dalam penelitian ini yaitu perempuan penyintas erupsi Merapi. Alat ukur yang digunakan yaitu skala resiliensi, observasi dan wawancara. Skala resiliensi merupakan modifikasi dari skala resiliensi Yu dan Zhang (2007). Penelitian ini menggunakan uji mann-whitney dengan gained score. Hasil dari uji mann-whitney menunjukkan bahwa terdapat perbedaan skor resiliensi yang sangat signifikan saat pascates antara kelompok eksperimen dan kelompok kontrol yang ditunjukkan dengan $\mathrm{F}=-3,210, \mathrm{P}=0,001(\mathrm{P}<0,01)$. Hal ini menunjukkan bahwa pelatihan koping religius efektif untuk meningkatkan resiliensi pada perempuan penyintas erupsi Merapi.
\end{abstract}

Kata kunci: koping religius, resiliensi 
Sebagai negara yang memiliki banyak gunung aktif, Indonesia menjadi negara yang rawan terhadap terjadinya letusan gunung berapi. Pada tahun 2010, Daerah Istimewa Yogyakarta dan Jawa Tengah telah digemparkan oleh adanya letusan gunung berapi. Letusan Gunung Merapi tersebut telah menelan banyak korban jiwa dan kerugian tak terhingga. Setiawan (2011) menjelaskan hingga bulan Februari 2011, kerugian diperkirakan mencapai Rp 5,4 triliun dengan kerugian yang ditimbulkan oleh lahar dingin mencapai lebih dari Rp 30 miliar. Angka ini terus bertambah mengingat ancaman lahar dingin yang terus terjadi.

Pasca terjadinya erupsi Merapi, kondisi fisik dan psikologis para korban yang selamat sangat memprihatinkan. Kehilangan harta benda, mata pencaharian serta keluarga menjadi sebuah pukulan berat, bahkan para korban selamat ini yang dalam Kamus Besar Bahasa Indonesia (2010) disebut sebagai penyintas-- ditantang untuk bisa bertahan dalam situasi bencana.

Tekanan yang dialami oleh penyintas muncul dari perubahan yang terjadi begitu cepat sehinga menjadi beban tersendiri. Ahmed (2011) melaporkan hasil survei yang dilakukan oleh Plan Indonesia yang bekerjasama dengan Fakultas Psikologi UI mengenai dampak erupsi Merapi menunjukkan bahwa $25 \%$ kaum muda beresiko terhadap tekanan psikologis yang berdampak pada perasaan tidak berdaya, frustrasi, depresi dan kehilangan harapan akan masa depan dan $43 \%$ mengalami kesulitan dalam berbagai tingkatan terutama gejala emosional dan masalah perilaku. Hal yang sama juga dialami oleh penyintas tsunami di Srilanka. Hasil penelitian yang dilakukan Hollifield, Hewage, Gunawardena, dan Kodituwakku (2008) pada penyintas tsunami Srilanka setelah 21-24 bulan peristiwa tsunami menemukan bahwa beberapa orang dewasa mengalami gejala kejiwaan dan somatik yang meliputi PTSD, depresi serta kecemasan.

Pasca erupsi Merapi tahun 2010, penyintas ditantang untuk melanjutkan hidup setelah musibah yang mereka alami. Hunian sementara dibangun agar para penyintas dapat bangkit dan pulih dari kemalangan serta memulai suatu hal yang baru. Tidak mudah, tetapi penyintas berusaha untuk bangkit dengan sumber daya yang dimiliki. Penyintas mencoba menyesuaikan diri dengan perubahan yang dialami. Beberapa di antaranya mampu menyesuaikan diri dan dapat melanjutkan hidup walaupun dengan kondisi yang terbatas. Beberapa lainnya tidak mampu menghadapi perubahan sehingga sulit melanjutkan hidup dalam kondisi kemalangan.

Penyintas merasa tidak memiliki kekuatan untuk bangkit, padahal setiap manusia diberikan suatu kekuatan untuk menghadapi kemalangan yang dialami agar menemukan kemudahan dalam 
kesulitan. Seperti yang tertulis dalam alQur'an surat al-Insyirah ayat 6 yang artinya bahwa "Sesungguhnya sesudah kesulitan itu ada kemudahan". Kekuatan tersebut tidak dirasakan oleh para penyintas karena kemalangan yang telah menghabiskan seluruh harta benda, keluarga serta mata pencarian dirasakan berat. Surat Al Insyirah ayat 6 menunjukkan bahwa kesulitan yang ada akan dikalahkan oleh kemudahan dan tidak seorang pun akan terus dirundung kemalangan. Tentu saja dalam hal ini individu harus berjuang dengan kekuatan yang dimiliki dan bersikap optimis terhadap tekanan yang ada. Kekuatan yang dimaksud adalah resiliensi. Resiliensi mencerminkan adanya kekuatan yang dimiliki individu untuk bangkit dari kemalangan.

Resiliensi merupakan kemampuan yang sangat dibutuhkan individu karena kehidupan manusia senantiasa diwarnai oleh kesengsaran sehingga individu dituntut untuk mampu memecahkan masalah dengan baik dan memiliki strategi koping yang efektif (Everall, Altrows, \& Paulson, 2006). Yu dan Zhang (2007) mengungkapkan bahwa resiliensi melindungi seseorang dari efek negatif situasi yang sulit. Resiliensi sangat berperan dalam pemulihan dari trauma atau meminimalisasi resiko dari PTSD (Reivich \& Shatte, 2002).

Jhonson, Dinsmore, dan Hof (2011) mendeskripsikan seorang yang tidak resilien sebagai individu yang rentan terhadap lingkungan yang beresiko. Individu yang tidak resilien sulit melakukan adaptasi terhadap situasi menekan dan tidak bisa mengendalikan emosinya sehingga cenderung larut dalam situasi kemalangan. Kekhawatiran terhadap suatu hal yang baru menyebabkan orang yang tidak resilien sulit untuk melakukan perubahan.

Tidak berbeda jauh dengan pandangan di atas, Tedeschi dan Kilmer (2005) menyebutkan bahwa individu yang tidak resilien dapat dilihat dari level aktivitas yang rendah, kurang responsif terhadap orang lain, komunikasi yang buruk, orientasi sosial yang buruk, kurangnya motivasi untuk mengembangkan diri sendiri, kurangnya kontrol lokus internal, kurangnya kemampuan untuk fokus, berwatak negatif, pesimis, efikasi diri yang rendah, kepercayaan diri yang rendah serta kurang adanya dukungan dan keteraturan dalam lingkungannya. Sayangnya, kondisi tidak resilien ini dialami oleh penyintas erupsi Merapi.

Salah satu faktor yang memengaruhi resiliensi adalah koping (coping). Koping didefinisikan Lazarus dan Folkman (Synder \& Lopez, 2002) sebagai suatu proses yang dilakukan untuk mengatasi tuntutan dari dalam dan luar yang dianggap menimbulkan ketegangan yang melebihi kapasitas individu. Koping yang baik akan mengarahkan pada pertumbuhan yang baik, sebaliknya koping yang buruk 
mengarahkan pada penyesuaian diri yang buruk.

Pada penelitian ini koping akan digunakan sebagai penguatan resiliensi. Penelitian terdahulu tentang penguatan resiliensi telah banyak dilakukan, di antaranya pelatihan manajemen stres, pelatihan regulasi emosi, dan pelatihan koping fokus emosi. Adanya kelemahan dari beberapa bentuk penguatan resiliensi yang ada membuat peneliti tertarik untuk melakukan penguatan resiliensi dengan menggunakan koping religius.

Komponen religius sering digunakan untuk bangkit dari bencana. Survei nasional tentang reaksi stres yang dilakukan di Amerika Serikat setelah terjadinya peristiwa serangan 11 September, menemukan bahwa kembali kepada agama (berdoa, perasaan spiritual) adalah koping umum kedua terbanyak yang dilakukan setelah berbicara dengan orang lain (Schuster dkk, 2001). Peres, Almeida, Nasello, dan Koenig (2007) menyebutkan bahwa saat mengalami peristiwa traumatik atau peristiwa menekan, banyak orang menggunakan koping yang didasarkan pada keyakinan agamanya. Hal ini sangat sesuai dengan yang diungkapkan oleh Folkman dan Moskowitz (2004) bahwa seringkali agama digunakan pada saat seseorang membutuhkan bantuan dalam menghadapi situasi yang menekan, terutama dalam menemukan kekuatan untuk bertahan dan makna dari kesulitan yang menantang kehidupan.

Pargament, Feullie, dan Burdzy (2011) mendefinisikan koping religius sebagai suatu usaha yang dilakukan untuk memahami dan mengatasi tekanan hidup dengan cara yang suci (bersih). Karekla dan Canstantinou (2010) mengatakan bahwa koping religius melibatkan proses kognitif dan perilaku yang muncul dari agama seseorang saat menghadapi situasi yang menekan. Cara kognitif dilakukan dengan melibatkan penilaian terhadap suatu kejadian sebagai rencana dari Tuhan sedangkan komponen perilaku dilakukan dengan menggunakan praktek-praktek religius seperti beribadah, berdoa sebagai jalan keluar yang ditawarkan oleh agama.

Pada penelitian ini, koping religius yang digunakan adalah dengan mengajak para penyintas erupsi Merapi melihat peristiwa bencana dengan cara yang lebih positif, yaitu melalui agama. Penilaian positif terhadap bencana dapat menumbuhkan harapan dan keyakinan bagi penyintas akan kekuatan yang dimiliki. Praktek religius juga dilakukan, yaitu berzikir. Praktik religius zikir ini merupakan salah satu yang dapat membantu penyintas untuk mengendalikan emosi serta memberikan perasaan nyaman dan tenteram. Penyintas merasa memiliki kedekatan dengan Yang Maha Kuasa sehingga merasa yakin akan bantuan Tuhan. Membina hubungan dengan saling membantu juga diajarkan pada 
penyintas, karena hubungan yang terbina akan membentuk suatu kedekatan antar sesama sehingga memunculkan rasa dukungan yang saling menguatkan satu sama lain.

Pemberian koping religius untuk meningkatkan resiliensi akan dilakukan dengan menggunakan metode pelatihan. Dijelaskan oleh Sallas dan Paton (Paton, Violanti, \& Smith, 2003) bahwa faktor kunci untuk meningkatkan resiliensi adalah dengan memberikan kemampuan untuk menerapkan keterpaduan dan makna dari pengalaman, yaitu dengan pelatihan. Pelatihan dipilih karena dengan pelatihan akan terjadi proses pembelajaran yang melibatkan partisipan secara penuh dan total (Supratiknya, 2008). Pada penelitian yang akan dilakukan oleh peneliti, koping religius merupakan intervensi yang akan diberikan kepada penyintas yang memiliki resiliensi rendah.

Penelitian tentang koping religius memang masih sangat jarang dilakukan terutama di Indonesia, namun sudah dilakukan di beberapa negara. Penelitian tentang religius koping banyak dilakukan dalam bidang kesehatan, salah satunya yang dilakukan dilakukan oleh $\mathrm{Ai}$, Dunkle, Peterson dan Bolling (1998) terhadap pasien bedah jantung. Penelitian tersebut menggunakan doa sebagai bentuk koping religius untuk membantu proses pemulihan pasien bedah jantung. Hasil penelitian menunjukkan bahwa berdoa membantu pasien dalam pemulihan setelah menjalani bedah jantung. Pasien menunjukkan kondisi psikologis yang lebih baik, karena merasa berdoa membantu untuk mengendalikan emosi yang berlebihan.

Pentingnya penggunaan intervensi religius dijelaskan oleh Ganje-Fling dan McCarthy (McCarthy \& Houg, 2008) bahwa intervensi religius berguna untuk menciptakan hubungan antara individu dengan Tuhan yang memiliki kekuatan di luar kendali manusia. Hal tersebut mampu menumbuhkan harapan dan keyakinan. Penggunaan keyakinan religius juga sangat membantu dalam proses pemulihan saat sedang menghadapi kesulitan hidup (Swank \& Pargament, 2005). Hal tersebut menjadi alasan peneliti untuk melakukan penelitian ini. Erupsi Merapi yang telah menghilangkan seluruh harta benda dan pekerjaan membuat penyintas tidak resilien. Koping religius akan meningkatkan resiliensi penyintas dengan menumbuhkan harapan dan keyakinan agar penyintas dapat bangkit dari kemalangan.

Berangkat dari pemaparan di atas, maka dapat dirumuskan hipotesis dalam penelitian ini, yaitu ada pengaruh pelatihan koping religius untuk meningkatkan resiliensi para penyintas erupsi Merapi. 


\section{METODE PENELITIAN}

\section{Subjek Penelitian}

Subjek pada penelitian ini adalah perempuan penyintas Erupsi Merapi 2010 yang tinggal di shelter Gondang 1 Sleman dan berusia 20 tahun ke atas. Subjek memiliki skor resiliensi dengan kategori sedang atau rendah. Subjek dalam penelitian ini beragama Islam dan bersedia mengikuti pelatihan yang diberikan.

\section{Rancangan Penelitian}

Penelitian ini merupakan penelitian kuasi eksperimen atau eksperimen semu. Pada penelitian ini desain yang digunakan adalah nonrandomized pretest-posttest control group design. Desain ini bertujuan untuk melihat efek dari suatu perlakuan terhadap variabel tergantung pada kelompok eksperimen setelah dikenai perlakuan dengan kelompok kontrol yang tidak dikenai perlakuan. Rancangan eksperimen yang digunakan dalam penelitian ini adalah:

Tabel 1. Rancangan Eksperimen Penelitian

\begin{tabular}{cccccc}
\hline \multirow{2}{*}{ NR } & Kelompok & Prates & Perlakuan & Pascates & $\begin{array}{c}\text { Tindak } \\
\text { lanjut }\end{array}$ \\
\cline { 2 - 6 } & KE & O1 & X & O2 & O3 \\
& KK & O1 & $-\mathrm{X}$ & O2 & O3 \\
\hline
\end{tabular}

Keterangan :

$\mathrm{KE}=$ Kelompok Eksperimen

$\mathrm{KK}=$ Kelompok Kontrol

NR $=$ Non Random

O1 = Pengukuran sebelum perlakuan (Prates)

$\mathrm{O} 2=$ Pengukuran setelah perlakuan (Pascates)

$\mathrm{O} 3=$ Pengukuran saat Tindak lanjut

\section{Metode Pengumpulan Data}

Penelitian ini menggunakan skala resiliensi. Skala resiliensi yang akan digunakan merupakan modifikasi skala CD-RISC dari Yu dan Zhang (2007). Skala ini terdiri atas tiga aspek, yaitu tenacity, strength dan optimism. Skala yang digunakan terdiri atas pernyataan favorabel (pernyataan yang mendukung skala resiliensi pada penyintas erupsi Merapi). Skala resiliensi ini menggunakan skor yang bergerak dari 15. Penilaian butir selalu diberi skor 5, sering diberi skor 4, kadang diberi skor 3, jarang diberi skor 4 dan tidak pernah diberi skor 1 . 
Wawancara dan observasi dalam penelitian ini digunakan untuk memperoleh data yang dianalisis secara kualitatif. Wawancara dilakukan terhadap penyintas erupsi Merapi di awal dan di akhir penelitian. Wawancara di awal penelitian dilakukan dengan tujuan untuk menganalisis kebutuhan penyintas erupsi Merapi, sehingga perlakuan yang diberikan pada penelitian ini diharapkan dapat bermanfaat dan sesuai kebutuhan penyintas. Wawancara di akhir penelitian dilakukan dalam rangka tindak lanjut (follow up). Hal ini dilakukan untuk mengetahui sejauh mana penyintas erupsi Merapi yang mendapatkan perlakuan mengambil manfaat dari perlakuan tersebut serta sejauhmana penyintas dapat menerapkannya dalam kehidupan sehari-hari.

Hasil observasi diperoleh dari pengamatan terhadap peserta pada saat pelaksanaan pelatihan koping religius. Ada beberapa aspek terkait peserta dalam pelatihan ini yang diobservasi, antara lain partisipasi peserta, keaktifan peserta, motivasi peserta, kesungguhan peserta dalam mengerjakan tugas, kerjasama antar peserta, dan perhatian peserta terhadap materi yang disampaikan.

\section{Intervensi Penelitian}

Pelatihan koping religius dilakukan dengan menggunakan koping religius positif. Pemberian koping religius disesuaikan dengan agama dari subjek penelitian, yaitu Islam. Menurut Aflakseir dan Coleman (2010), koping religus dalam Islam dilakukan dengan menggunakan ajaran Islam. Penekanan pada konteks Islam dilakukan pada keyakinan dan praktek religius sebagai sumber daya untuk menghadapi kesulitan dalam hidup. Pelatihan koping religius diberikan dalam beberapa bentuk, yaitu:

1. Menemukan makna kebaikan Tuhan (Allah SWT)

2. Allah SWT memiliki kendali di luar kekuatan manusia.

3. Berdzikir untuk mengingat Allah SWT

4. Membina hubungan dengan saling menolong sesama

Dalam pelatihan terdapat beberapa tahapan, yaitu:

1. Persiapan pelatihan

Persiapan pelatihan meliputi analisis kebutuhan dengan melakukan wawancara kepada penyintas, penyusunan modul, persiapan alat dan materi pelatihan, seleksi serta pembekalan fasilitator, co-fasilitator dan observer.

2. Pengukuran awal (prates)

Pengukuran awal dilakukan untuk mengetahui keadaan awal peserta. Pengukuran awal dilakukan dengan menggunakan skala resiliensi. Pengukuran awal ini juga mendapatkan hasil prates dari skor tryout terpakai. Pengukuran awal 
dilakukan pada tanggal 13-15 September 2012.

3. Pelaksanaan pelatihan

Pelatihan dilaksanakan di shelter Gondang 1 Sleman pada pukul 14.30-17.00 wib. Pelatihan dilaksanakan sebanyak empat kali pertemuan dari tanggal 24 September - 4 Oktober 2012. Setiap minggu dilaksanakan 2 kali pertemuan sehingga total waktu yang digunakan yaitu 2 minggu. Adapun kegiatan yang dilakukan:

Tabel 2. Kegiatan Pelatihan Koping Religius

\begin{tabular}{cl}
\hline Pertemuan & \multicolumn{1}{c}{ Kegiatan } \\
\hline $\begin{array}{c}\text { Pertemuan } \\
1\end{array}$ & $\begin{array}{l}\text { Perkenalan dan penjelasan pelatihan, mengetahui harapan } \\
\text { peserta, pemberian materi } \mathrm{ABC} \text { dan Latihan } \mathrm{ABC} \text {, belajar melalui } \\
\text { film religi kun fayakun }\end{array}$ \\
$\begin{array}{c}\text { Pertemuan } \\
\text { Pertemuan }\end{array}$ & $\begin{array}{l}\text { Penjelasan dzikir 1 dan latihan dzikir bersama } \\
\text { tolong menolong }\end{array}$ \\
$\begin{array}{c}\text { Pertemuan } \\
4\end{array}$ & $\begin{array}{l}\text { Review keseluruhan materi pelatihan, terminasi dan evalusi } \\
\text { pelatihan }\end{array}$ \\
\hline
\end{tabular}

4. Pengukuran setelah pelatihan (posttest)

Pascates merupakan pengukuran kedua yang dilakukan segera setelah pemberian perlakuan. Pascates bertujuan untuk melihat pengaruh pelatihan koping religius untuk meningkatkan resiliensi peserta. Pascates dilakukan dengan memberikan skala resiliensi yang dilakukan pada tanggal 4 Oktober 2012.

5. Tindak lanjut (follow up)

Tindak lanjut merupakan pengukuran terakhir yang diberikan kepada peserta dengan jeda waktu 2 minggu setelah dilaksanakannya pascates. Tindak lanjut bertujuan untuk melihat sejauh mana pengaruh pelatihan dan penerapannya dalam kehidupan sehari-hari. Tindak lanjut dilaksanakan pada tanggal 20 Oktober 2012 dengan membagikan skala resiliensi.

6. Pelaksanaan pelatihan pada kelompok waiting list

Kelompok waiting list mendapat perlakuan sama seperti kelompok eksperimen. Pelaksanaan pelatihan dilakukan segera setelah pemberian perlakuan pada kelompok eksperimen berakhir. 
Teknik Analisis Data

Analisis data yang digunakan dalam penelitian ini adalah analisis kuantitatif dan analisis kualitatif. Analisis data kuantitatif akan dilakukan dengan menggunakan paket Statistical Product and Service Solution (SPSS) for windows. Pengujian hipotesis dalam penelitian ini dilakukan dengan analisis non parametrik karena jumlah sampel yang kecil. Teknik yang digunakan adalah $U$ Mann Whitney. Teknik Mann Whitney adalah uji beda yang digunakan untuk membandingkan dua kelompok yang tidak berhubungan (Santoso, 2005).

\section{HASIL PENELITIAN}

\section{Hasil Analisis Kuantitatif}

Sebelum dilakukan uji hipotesis, dilakukan uji prasyarat, yaitu uji normalitas dan uji homogenitas. Hasil uji normalitas dan homogenitas dapat dilihat pada tabel di bawah:

Tabel 3. Rangkuman Hasil Uji Normalitas Skala resiliensi

\begin{tabular}{lcccccc}
\hline Perlakuan & \multicolumn{3}{c}{ Eksperimen } & \multicolumn{3}{c}{ Kontrol } \\
\cline { 2 - 7 } & K-SZ & $\mathrm{P}$ & KET & K-SZ & $\mathrm{P}$ & KET \\
\hline Prates & 0,821 & 0,511 & Normal & 0.582 & 0,887 & Normal \\
Pascates & 0,799 & 0,546 & Normal & 0.895 & 0.400 & Normal \\
$\begin{array}{l}\text { Tindak } \\
\text { lanjut }\end{array}$ & 0,588 & 0,879 & Normal & 0.491 & 0.970 & Normal \\
\hline
\end{tabular}

Tabel 4. Rangkuman Hasil Uji Homogenitas Skala Resiliensi

\begin{tabular}{lccc}
\hline Perlakuan & Levene Statistic & p & Keterangan \\
\hline Prates & 2,440 & 0,141 & Homogen \\
$\begin{array}{l}\text { Eksperimen } \\
\text { kontrol }\end{array}$ & & & \\
\hline
\end{tabular}

Setelah uji prasyarat terpenuhi, pengujian hipotesis dilakukan dengan uji statistik, yaitu uji mann-whitney dengan gained score. Hasil analisis data dengan uji mann-whitney gain score terdapat pada berikut: 
Tabel 5. Rangkuman Uji Mann-Whitney Gain Score pada Kelompok Eksperimen dan Kontrol

\begin{tabular}{|c|c|c|c|}
\hline Pengukuran & $\mathbf{Z}$ & $\mathbf{P}$ & Keterangan \\
\hline Prates-Pascates & $-3,210$ & 0,001 & $\begin{array}{c}\text { Sangat } \\
\text { Signifikan }\end{array}$ \\
\hline Pascates-Tindak lanjut & $-3,268$ & 0,001 & $\begin{array}{c}\text { Sangat } \\
\text { Signifikan }\end{array}$ \\
\hline
\end{tabular}

Dari hasil hasil uji mann-whitney dengan menggunakan gain score pada prates dan pascates diketahui bahwa ada perbedaan resiliensi pada subjek penelitian. Hal ini ditunjukkan dengan nilai $Z=-3,210 p=0,001$ ( $p>0,01)$. Pada pascates dan tindak lanjut, hasil analisis juga menunjukkan bahwa ada perbedaan resiliensi pada subjek penelitian. Hal ini ditunjukkan dengan nilai $Z=-3,268$ $p=0,001 \quad(p>0,01)$. Dengan demikian dapat disimpulkan bahwa ada perbedaan resiliensi antara kelompok eksperimen yang diberikan perlakuan pelatihan koping religius dan kelompok kontrol yang tidak diberikan perlakuan pelatihan koping religius. Hasil ini diperkuat oleh adanya perbedaan resiliensi pada kelompok eksperimen maupun kelompok kontrol setelah dilakukan tindak lanjut. Berdasarkan uji hipotesis di atas, maka dapat disimpulkan bahwa pelatihan koping religius dapat meningkatkan resiliensi. Dengan demikian, hipotesis yang berbunyi ada perbedaan peningkatan resiliensi antara kelompok yang mendapatkan pelatihan koping religius dan kelompok yang tidak mendapatkan pelatihan koping religius diterima.

\section{Hasil Analisis Kualitatif}

Berdasarkan hasil uji kualitatatif, diketahui bahwa peserta mengalami proses koping religius yang berbeda saat pelatihan dilakukan. Kesungguhan peserta dalam mengikuti pelatihan koping religius terlihat dari aktifnya para peserta dalam mengikuti kegiatan serta mengerjakan lembar tugas. Adanya kenaikan skor nilai yang berbeda dapat disebabkan oleh berbagai faktor seperti proses kognitif, serta permasalahan yang dihadapi. Secara keseluruhan para peserta dapat memahami maksud dan tujuan pelatihan koping religius, tidak ada kendala berarti saat proses pelatihan dilakukan.

\section{PEMBAHASAN}

Penelitian ini bertujuan untuk menguji pengaruh pelatihan koping religius terhadap peningkatan resiliensi pada perempuan penyintas erupsi Merapi. Hasil yang diperoleh menunjukkan bahwa pelatihan koping religius berpengaruh 
terhadap peningkatan resiliensi perempuan penyintas erupsi Merapi. Berdasarkan analisis uji mann-whitney gained score yang dilakukan menunjukkan bahwa ada perbedaan resiliensi antara kelompok eksperimen yang diberikan perlakuan pelatihan koping religius dan kelompok kontrol yang tidak diberikan perlakuan pelatihan koping religius. Uji mann-whitney gained score prates dan pascates pada kelompok eksperimen maupun kelompok kontrol menunjukkan ada perbedaan resiliensi yang sangat signifikan dengan $Z=-3,210$, $p=0,001,(p<0,01)$. Uji mann-whitney gained score pascates dan tindak lanjut resiliensi pada kelompok eksperimen maupun kelompok kontrol menunjukkan juga ada perbedaan resiliensi dengan Z = 3,268, $p=0,001$ ( $p>0,01)$.

Dari penjelasan di atas dapat ditarik simpulan bahwa pelatihan koping religius dapat meningkatkan resiliensi perempuan penyintas erupsi Merapi. Pada pelatihan koping religius ini penyintas diajarkan untuk menemukan makna kebaikan Allah SWT, menyadari bahwa Allah SWT memiliki kendali di luar kekuatan manusia, mengingat Allah untuk memperoleh kenyamanan (pengendalian emosi), serta membina hubungan untuk saling menolong.

Tahap awal pelatihan koping religius adalah melatih para penyintas untuk menemukan makna kebaikan Allah SWT. Pada tahap ini penyintas dilatih untuk menemukan makna dari peristiwa yang dialami. Penyintas dilatih untuk melihat sisi positif dari peristiwa erupsi Merapi. Pikiran dan anggapan buruk penyintas terhadap peristiwa erupsi Merapi yang terjadi diubah dengan cara memberikan pemikiran baru dan pemahaman yang lebih positif melalui agama. Pentingnya proses ini dilakukan karena saat peristiwa traumatik terjadi (erupsi Gunung Merapi), individu melakukan proses kognitif yang akan memengaruhi cara pandang terhadap peristiwa traumatik tersebut (Mclntosh, Poulin, Silver, \& Holman, 2011). Pengalaman bencana yang terjadi memengaruhi reaksi terhadap bencana tersebut.

Adanya pemikiran yang lebih positif terhadap bencana yang terjadi menciptakan makna yang dapat dijadikan pelajaran. Menurut Koenig (Safaria dkk, 2010), adanya makna yang terbentuk dari suatu pemikiran dan interpretasi yang positif akan menimbulkan suatu harapan serta perasaan positif. Harapan yang dimiliki memunculkan rasa optimis dan keyakinan dalam mengahadapi kemalangan. Harapan yang dimiliki penyintas menjadi kekuatan internal untuk lebih resilien karena adanya keyakinan bahwa terdapat jalan keluar dari masalah yang dihadapi. Hal ini senada dengan hasil penelitian yang dilakukan oleh Ong, Bergeman, Bisconti, dan Wallace (2006) bahwa harapan membantu menjadi lebih resilien karena harapan yang muncul saat makna dari situasi sulit terbentuk 
mengurangi tekanan yang dirasakan.

Tahap kedua dari pelatihan koping religius adalah menyadari kekuatan Tuhan di luar kendali manusia. Pada tahap ini penyintas diharapkan mampu menerima kondisi yang dialami dengan cara menyadari kelemahan dan kekuatan diri. Reivich dan Shatte (2002) menjelaskan bahwa dengan menyadari kekuatan dan kelemahan diri akan membantu seseorang menjadi lebih resilien karena mengetahui batasan-batasan yang dimiliki.

Tuhan yang maha menciptakan dan mengendalikan merupakan tempat untuk berserah diri dengan keyakinan bahwa akan datangnya pertolongan. Keyakinan akan adanya pertolongan dari Tuhan memunculkan rasa optimis dan kepercayaan diri dalam menghadapi kesulitan. Rasa optimis dan kepercayaan diri ini meningkatkan resiliensi karena menggerakkan individu mencari solusi dan tetap bekerja keras untuk meningkatkan situasi (Luthans, Vogelgesang, \& Lester, 2006). Hal ini sesuai dengan hasil penelitian Pardini, Plant, Sherman, dan Stump (2000) bahwa keyakinan religius akan adanya bantuan dari Tuhan membuat individu lebih resilien karena lebih optimis dalam menjalani hidup dan tingkat kecemasannya pun rendah.

Pada tahap ketiga koping religius, penyintas dilatih melakukan praktek religius, yaitu zikir untuk memperoleh pengendalian dan ketenangan. Saat menghadapi situasi menekan, emosi yang muncul sangat dipengaruhi oleh peristiwa yang terjadi. Pada penyintas erupsi Merapi, emosi negatif seperti rasa takut, sedih muncul dari pikiran terhadap bencana. Untuk itu penyintas diberikan kemampuan untuk mengendalikannya dengan cara berzikir. Saat berzikir individu merasa tidak sendirian dalam menghadapi masalah. Melalui zikir individu mengeluarkan keluh kesah yang dialami. Hal ini membantu individu memperoleh ketenangan, rasa pengendalian sehingga kemudian menekan kerja sistem syaraf simpatetis dan mengaktifkan kerja sistem syaraf parasimpatetis (Saleh, 2010). Kondisi ini yang disebut dengan efek relaksasi. Adanya efek relaksasi setelah melakukan zikir dapat memberikan ketenangan, dan rasa pengendalian bagi penyintas erupsi Merapi walaupun dalam situasi yang tidak menyenangkan. Hal ini sesuai dengan penelitian yang dilakukan oleh Peres dkk (2007) dan Hebert, Dang, \& Schulz (2007) bahwa praktek religius seperti berdoa dapat memberikan kenyamanan, harapan, serta kesehatan mental yang lebih baik. Menurut Reich, Zautra dan Hall (2010) kemampuan mengendalikan emosi membantu individu menjadi resilien karena seorang yang resilien tidak larut dalam situasi yang tidak menyenangkan tetapi memiliki cara menghadapinya. Hal ini senada dengan hasil penelitian yang dilakukan oleh Annalakshmi dan Abeer (2011) bahwa praktek religius dalam Islam dapat meningkatkan resiliensi, 
menciptakan kesehatan yang lebih baik, karena individu yang resilien akan mencari solusi saat menghadapi masalah.

Tahap selanjutnya yang dilakukan dalam pelatihan koping religius adalah mengajarkan untuk saling menolong. Pada tahap ini diajarkan bahwa tolong menolong dapat dibentuk melalui berbagai macam cara. Salah satunya dengan membina hubungan antara sesama. Tolong menolong dapat membantu penyintas menjadi resilien karena adanya dukungan yang diperoleh antar sesama. Dukungan yang ada saling menguatkan satu sama lain saat tertimpa musibah, serta membentuk rasa kedekatan. Dukungan dan rasa kedekatan menjadi sumber kekuatan yang dimiliki oleh penyintas untuk bangkit. Adanya dukungan yang diperoleh mengurangi tekanan yang dirasakan saat menghadapi musibah. Hal ini sesuai dengan penelitian yang dilakukan oleh Rodin dan Stewart (2012) dan Taylor dkk (2010) bahwa membina hubungan sosial dan saling membantu memberikan rasa dukungan yang membuat seseorang menjadi lebih resilien dalam menghadapi kemalangan.

Proses-proses yang dialami selama pelatihan koping religius ini sangat berkaitan erat dengan peningkatan resiliensi penyintas erupsi Merapi. Hal-hal yang diberikan selama pelatihan merupakan suatu upaya untuk memberikan pemahaman baru terkait bencana serta memberikan keterampilan baru dalam mengatasi bencana melalui agama. Saat menghadapi situasi yang di luar batas manusia, agama seringkali digunakan untuk mengatasi permasalahan. Agama memberikan penyesuaian positif setelah terjadinya peristiwa sulit. Cara pandang yang lebih positif terhadap suatu permasalahan membuat agama dirasakan dapat memberi rasa aman dan nyaman serta menawarkan jalan keluar saat menghadapi masalah (Mclntosh dkk, 2011).

Keberhasilan pelatihan yang telah dicapai dalam meningkatkan resiliensi perempuan penyintas erupsi Merapi dipengaruhi oleh beberapa faktor penting yang menentukan dalam suatu pelatihan, yaitu modul pelatihan, fasilitator, dan karakteristik subjek dalam pelatihan tersebut (Grieshaber, 1994). Metode atau teknik yang dipakai dalam modul pelatihan koping religius ini antara lain melalui ceramah, presentasi materi dan diskusi sehingga tidak membuat peserta merasa jenuh dan bosan dalam menjalani setiap sesi dalam pelatihan.

Keberhasilan pelatihan ini juga didukung oleh desain pelatihan dalam penelitian ini yang mengacu pada aktivitas-aktivitas pembelajaran melalui pengalaman (experiental learning), yakni belajar melalui pengalaman, proses pembelajaran akan menjadi efektif karena individu mendapatkan stimulasi yang berulang melalui berbagai indra, baik penglihatan, pendengaran, pengecapan, penciuman dan perabaan atau kinestetik (Afiatin, 2004). 
Secara kualitatif penelitian ini menemukan bahwa kemampuan subjek terhadap peningkatan resiliensi berbedabeda jumlah skornya. Faktor-faktor yang menyebabkan munculnya perbedaan proses koping religius ini adalah kondisi berbeda yang dialami peserta pelatihan seperti kondisi kesehatan dan permasalahan yang sedang dihadapi, serta kemampuan peserta dalam menyerap materi-materi pelatihan dan proses belajar yang berbeda pada setiap peserta.

Pada penelitian ini, peneliti mendapatkan beberapa keterbatasan dalam menjalankan penelitian, di antaranya adalah waktu yang terbatas karena dilakukan sore hari serta kurangnya kontrol atau pengawasan dalam pemberian tugas rumah. Pada penelitian ini juga tidak didesain untuk pengontrolan tugas rumah, sehingga memengaruhi hasil tindak lanjut yang kurang baik. Pengontrolan tugas rumah ini dapat dilakukan dengan membuat desain tugas rumah yang lebih terinci untuk kegiatan setiap harinya, sehingga apa yang telah dilatihkan dalam pelatihan dapat diterapkan di rumah dan dalam kehidupan sehari-hari dengan lebih baik.

\section{SIMPULAN DAN SARAN}

\section{Simpulan}

Berdasarkan hasil penelitian yang telah dilakukan, maka dapat disimpulkan bahwa:
1. Ada perbedaan resiliensi antara kelompok eksperimen yang diberikan perlakuan pelatihan koping religius dengan kelompok kontrol yang tidak diberikan pelatihan koping religius. Proses-proses yang dialami selama pelatihan koping religius sangat berkaitan erat dengan peningkatan resiliensi pada penyintas erupsi Merapi.

2. Analisis kualitatif menemukan bahwa individu-individu mengalami proses koping religius dan peningkatan skor resiliensi yang berbeda-beda. Faktorfaktor yang menyebabkan munculnya perbedaan proses koping religius ini adalah kondisi berbeda yang dialami peserta pelatihan seperti kondisi permasalahan yang dihadapi, serta kemampuan kognitif peserta dalam menyerap materi-materi pelatihan dan proses belajar yang berbeda pada setiap peserta.

\section{Saran}

Pelatihan dalam penelitian ini tidak didesain dengan pengontrolan tugas rumah, sehingga memengaruhi hasil tindak lanjut yang kurang baik. Akan lebih baik jika pengontrolan tugas rumah ini dapat dilakukan oleh pihak keluarga atau orang terdekat lainnya, sehingga apa yang telah dilatihkan dalam pelatihan dapat diterapkan di rumah dan dalam kehidupan sehari-hari. 


\section{Daftar Pustaka}

Afiatin, T. (2004). Pengaruh Program Kelompok AJl dalam Peningkatan Harga Diri, Asertivitas, dan Pengetahuan Mengenai NAPZA untuk Prevensi Penyalahgunaan NAPZA pada Remaja. Jurnal Psikologi, No. 1, 28-54.

Ahmed. (2011). Kaum Muda Merapi $\mathrm{R}$ e $\mathrm{ntan} \mathrm{Frustras}$. http://www.suaramerdeka.com.20/ $11 / 11$.

Anonim. (2011). Kamus Besar Bahasa Indonesia. Jakarta: PT Gramedia Pustaka.

Annalakshmi, N \& Abeer, M. (2011). Islamic Worldview, Religious Personality and Resilience among Muslim Adolescent Students in India. Europe's Journal of Psychology, 716-738.

Everall, R.D., Altrows, K.J \& Paulson, B. L. (2006). Creating a Future: A Study of Resilience in Suicidal Female Adolescent. Journal of Counseling and Development, 84, 461-470.

Grieshaber, C. (1994). Step by Step Group Development. Feldafing: German Foundation for International Development, Centre for Food and Agriculture Development.

Hebert, R., Dang, Q dan Schulz, R. (2007). Religious Beliefs and Practices Are Associated With Better Mental
Health in Family Caregivers of Patients With Dementia: Findings From the REACH Study. American Journal of Geriatric Psychiatry, 15 (4), 292-300.

Hollifield, M., Hewage, C., Gunawardena, C. N., Kodituwakku, P., Bopagoda, K \& Weerarathnege, K. (2008). Symptoms and Coping in Sri Lanka 20-21 Months after the 2004 Tsunami. The British Journal of Psychiatry, 192, 39-44.

Jhonson, N., Dinsmore, J. A., \& Hof D.D. (2011). The Relationship between College Students Resilience Level and Type of Alcohol Use. International Journal of Psychology: A Biopsychosocial Approach, 8, 6782.

Karekla, M \& Constantinou, M. (2010). Religious Coping and Cancer: Proposing an Acceptance and Commitment Therapy Approach. Journal of Cognitive and Behavioral Practice, 17, 371-381.

Luthans, F., Vogelgesang, G. R., \& Lester, P. B. (2006). Developing the Psychological Capital of Resiliency. Human Resource Development Review, 5, 1 .

McCarthy, P \& Houg, B, L. (2008). The Role of Spirituality in the Ongoing Recovery Process of Female Sexual Abuse Survivors. Dissertation (unpublish). Minnesota: University of Minnesota. 
McIntosh, D, N., Poulin, M., Silver, C dan Holman, E. (2011). The District Roles of Spirituality and Religiosity in Physical and Mental Health after Collective Trauma: a National Longitudinal Study of Responses to 9/11 Attacks. Journal of Behavioral Medicine; 9331.

Pargament, K., Feuille, M., and Burdzy, D. (2011). The Brief Rcope: Current Psychometric Status of a Short Measure of Religious Coping. J Religions, 2, 51-76.

Peres, J.F., Almeida, M., Nasello, A.G \& Koenig, H. (2007). Spirituality and Resilience in Trauma Victims. Journal of Religion and Health, 46, 343-350.

Reivich, K., \& Shatte, A. 2002. The Resilience Factor. USA; Broadway Books.

Rodin, D \& Stewart D, E. (2012). Resilience in Elderly Survivors of Ch ild M a l t r e a t m e n t . Sagepublications: 1-9.

Santoso, S. (2005). Mengatasi berbagai Masalah Statistik dengan SPSS. Jakarta: PT. Elex Media Komputindo.

Schuster, M.A., Stein, B., Jaycox, L., Collins, R.L., Marshall,G.N., Elliott, M.N., Zhou, A.J., Kanouse, D.E., Morrison,J.L., \& Berry, S. (2001). A National Survey of Stress Reactions after the September 11, 2001, Terrorist Attacks. N Engl J Med, 345,
20.

Setiawan. (2011). Kerugian Erupsi Merapi 5,4 $\mathrm{T} r$ i l i u n . http://www.jurnas.com/news.11/22 $/ 11$

Synder, C.R \& Lopez, S.J. (2002). Handbook of Positive Psychology. New York; Oxford University Press.

Swank, N \& Pargament, K. (2005). God, Where are You? Evaluating a Spirituality-Integrated Intervention for Sexual Abuse. Journal of Mental Health, Religion and Culture, 8 (3), 191-203.

Taylor, M., Barr, M., Stevens, G., BrysonTaylor, D., Agho, K., Jacobs, J., Raphael, B. (2010). Psychosocial Stress and Stragies for Managing Adversity: Measuring Population Resilience in New South Wales, Australia. Population Health Metrics, 8, 28.

Tedeschi, R. G., \& Kilmer, R. P. (2005). Assessing Strengths, Resilience, and Growth to Guide Clinical Interventions. Professional Psychology: Research and Practice, 36 (3), 230-237.

Yu X. \& Zhang, J. (2007). Factor Analysis and Psychometric Evaluation of the Connor-Davidson Resilience Scale (CD RISC) with Chinese People. Social Behavior and Personality, 35, 19-30. 